\title{
Functional common gamma chain is not required for mast cell proliferation and survival
}

\author{
H Chapdelaine ${ }^{1,2^{*}}$, D Canioni ${ }^{3}$, G De Saint-Basile ${ }^{2,4}$, O Hermine $^{1,2}$, A Fischer $^{2,4,5}$ \\ From Canadian Society of Allergy and Clinical Immunology Annual Scientific Meeting 2012 \\ Calgary, Canada. 11-14 October 2012
}

\section{Background}

IL-15 is involved in the development and homeostasis of CD8 lymphocytes, NK and iNKT cells, and intraepithelial lymphocytes. It also promotes migration, proliferation and survival of mast cells. Its receptor on lymphocytes is a heterotrimeric complex which shares the IL2-R $\beta$ and common gamma $\left(\gamma_{c}\right)$ chains. IL-15-mediated signaling in mast cells might make use of an alternative receptor provisionally designated as IL-15RX. In a murine model, $\gamma_{\mathrm{c}}$-dependent signaling was shown to be essential for IL4- and IL-9-induced proliferation and survival of mast cells, but not IL-15 even in the wild-type mouse.

\section{Methods}

Skin biopsies of BCGitis lesions from 6 X-SCID patients were reviewed. Immunostaining using anti-CD117 (1/ 400, DAKO lab) and tryptase (1/400, DAKO lab) antibodies was performed. A similar BCGitis lesion from a patient with RAG SCID was tested with the same 2 antibodies as controls.

\section{Results}

Mast cells were present in the skin biopsies of all patients presenting with X-SCID ; their number was not decreased compared to normal skin biopsies. The number of mast cells in the skin biopsy of the RAG SCID patient was also normal.

\section{Conclusion}

These results suggest that, in humans, $\gamma_{c}$ is not required for mast cell proliferation and survival. Its impact on IL15-dependent migration and the possible role of IL-15RX warrant further studies.

\footnotetext{
* Correspondence: hugo.chapdelaine@videotron.ca

'Department of Hematology, Hôpital Necker-Enfants Malades, Assistance

Publique-Hôpitaux de Paris, Paris, France, 75743

Full list of author information is available at the end of the article
}

\section{Author details}

'Department of Hematology, Hôpital Necker-Enfants Malades, Assistance Publique-Hôpitaux de Paris, Paris, France, 75743. ${ }^{2}$ Centre de Référence Déficits Immunitaires Héréditaires, Hôpital Necker-Enfants Malades, France. ${ }^{3}$ Department of Pathology, Hôpital Necker-Enfants Malades, France. ${ }^{4}$ Centre d'Etudes des Déficits Immunitaires, Hôpital Necker-Enfants Malades, France. ${ }^{5}$ Department of Pediatric Immuno-Hematology, Hôpital Necker-Enfants Malades, France.

Published: 2 November 2012

doi:10.1186/1710-1492-8-S1-A22

Cite this article as: Chapdelaine et al:: Functional common gamma chain is not required for mast cell proliferation and survival. Allergy, Asthma \& Clinical Immunology 2012 8(Suppl 1):A22.
Submit your next manuscript to BioMed Central and take full advantage of:

- Convenient online submission

- Thorough peer review

- No space constraints or color figure charges

- Immediate publication on acceptance

- Inclusion in PubMed, CAS, Scopus and Google Scholar

- Research which is freely available for redistribution

\section{() Biomed Central}

